\title{
Radiastraea (Anthozoa, Rugosa) from the Emsian and Eifelian (Devonian) of Aviados, northern Spain
}

\author{
ANDREAS MAY
}

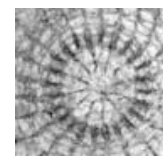

\begin{abstract}
This paper describes a colonial rugose coral from the upper Emsian or lower Eifelian of Aviados (Provincia León, northern Spain). This colony, which has been figured as Phillipsastrea torreana (Milne-Edwards \& Haime, 1851) by Almela \& Revilla (1950), belongs in fact to Radiastraea arachne Stumm, 1937. It is the first reported occurrence of the genus Radiastraea from Europe, and an example of close palaeobiogeographical relationships between the Cantabrian Mountains and North America during the Emsian. Cantabriastraea Schröder \& Soto, 2003 is probably only a marginal case of Radiastraea Stumm, 1937. The lectotype of Phillipsastrea torreana var. minuta Almela \& Revilla, 1950 from the upper Emsian to lower Eifelian or upper Givetian of Aviados (Provincia León, northern Spain) is designated and described in detail. It is a subspecies of Phillipsastrea torreana (Milne-Edwards \& Haime, 1851) with 10-12 major septa and a tabularium diameter of 1.9-2.1 mm. - Key words: Anthozoa, biogeography, Devonian, systematics, rugose corals, Spain.
\end{abstract}

MAY, A. 2006. Radiastraea (Anthozoa, Rugosa) from the Emsian and Eifelian (Devonian) of Aviados, northern Spain. Bulletin of Geosciences 81(3), 151-162 (2 figures). Czech Geological Survey, Prague. ISSN 1214-1119. Typescript received May 29, 2006; accepted in revised form June 28, 2006; issued September 30, 2006.

Andreas May, Saint Louis University - Madrid campus, Avenida del Valle 34, E-28003 Madrid, Spain; maya@madrid.slu.edu

The Museo Geominero in Madrid holds very important historical collections of fossils from Spain and the Western Sahara that are registered in an exemplary manner in a well developed database (Rabano \& Arribas 1997). This enables a revision of the Spanish Devonian corals in the Museo Geominero, which has been initiated by May (2005). As part of this work, the present author revises the original material of Almela \& Revilla (1950).

Among other fossils, Almela \& Revilla (1950) described and figured two distinct, but very similar colonial rugose corals of the genus Phillipsastrea from the "Couvinian" of Aviados on the southern slope of the Cantabrian Mountains. Both colonies are stored in the collections of the Museo Geominero. The fact that Almela \& Revilla (1950) gave clear information about the localities where the corals were found, but neither made any thin section of the corals, nor gave sufficient descriptions of them, motivated the present author to prepare thin sections of these colonies. Surprisingly, the thin sections show that these very similar looking corals are not closely related, and that only the colony named Phillipsastrea torreana var. minuta by Almela \& Revilla (1950, p. 58, p. 60, pl. 3, fig. 5) belongs to Phillipsastrea.

The other colony (Almela \& Revilla 1950, pl. 3, fig. 4) belongs to Radiastraea, an American genus which was not previously known from Europe and most of Asia. The find- ing of a Radiastraea species in the collections of the Museo Geominero is of particular interest, because it provides evidence of a close relationship between the Cantabrian Mountains and North America during the Emsian, which was the time of strongest faunal provincialism during the Devonian period. Consequently, the present paper gives a detailed description of the Radiastraea. Furthermore, to facilitate the distinction of this Radiastraea from superficially similar species of Phillipsastrea, Phillipsastrea torreana minuta Almela \& Revilla, 1950 is also described in detail.

\section{Provenance of the material}

The investigated colonies came from two different localities in the vicinity of Aviados (Provincia León). Both are classified as "Couvinian" by Almela \& Revilla (1950). Aviados is a very small village near La Vecilla de Curueño, on regional road LE-626 from La Robla to Boñar. The Aviados area has been famous since the nineteenth century for its wealth of fossil deposits, which occur in the Santa Lucía Formation (Méndez-Bedia et al. 1994, Fernández et al. 1995, p. 41). The Santa Lucía Formation belongs mainly to the upper Emsian, while only the uppermost part belongs to the lower Eifelian (García-López 1986, Méndez-Bedia et 


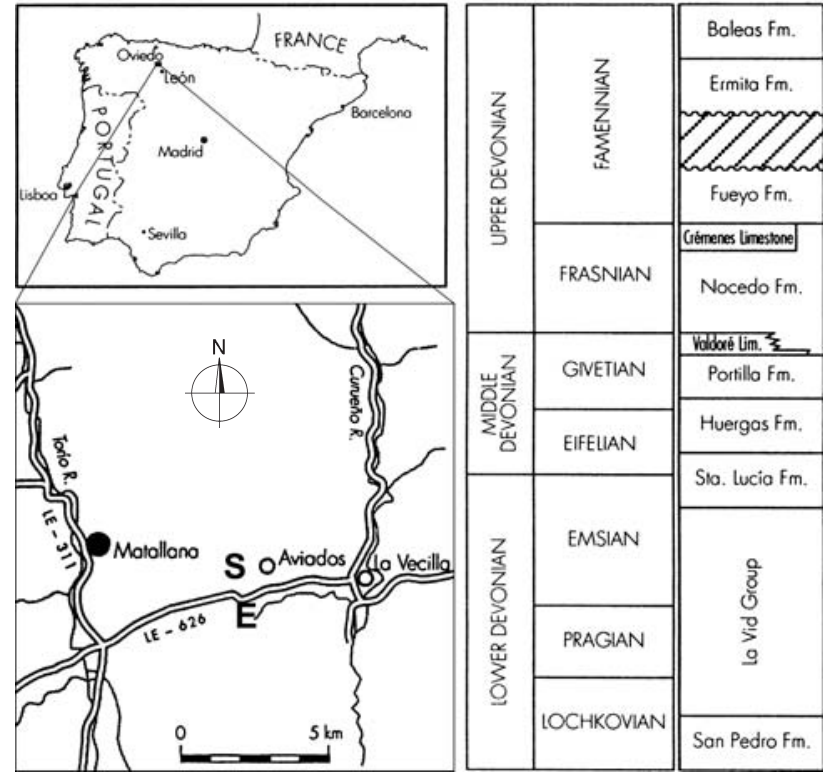

Figure 1. The geographical position of the localities and the stratigraphy of the Devonian in the area. E = outcrop "El Cueto", $\mathrm{S}=$ outcrop "Sierra Carro”. Modified after Fernández et al. (1995, figs 1, 8).

al. 1994, Fernández et al. 1995, García-Alcalde et al. 2002). It consists of a $250 \mathrm{~m}$ thick series of limestones and argillaceous limestones with interbedded thin shaly levels (Méndez-Bedia 1976; Méndez-Bedia et al. 1994, p. 164; Fernández et al. 1995, p. 16; Hofmann \& Keller 2006). Furthermore, the Portilla Formation, an upper Givetian limestone (Fernández et al. 1995, García-Alcalde et al. 2002), also crops out in the vicinity of Aviados. The geographical position of the localities and the stratigraphy of the Devonian in this area are shown in Fig. 1.

The colony now described as Radiastraea arachne (stock No. 1519D) comes from an outcrop on El Cueto hill, which lies one $\mathrm{km}$ southwest from Aviados, and whose top is comprised of grey limestones (Almela \& Revilla 1950, p. 50). Almela \& Revilla (1950, pp. 50-51) collected their fossils from the top, the northern slope, and the western slope of the hill up to the cliff that limits El Cueto.

Almela \& Revilla (1950, p. 51) reported brachiopods from the limestones of the El Cueto outcrop, including Spirifer cultrijugatus. Regardless of whether this was a true Paraspirifer cultrijugatus (F. Roemer, 1844) or only another species of Paraspirifer, the stratigraphical information is evident: Paraspirifer originated in the lower upper Emsian and became extinct in Europe and Northern Africa at the end of the lower Eifelian (Godefroid 1980, pp. 85-92, May 1996, pp. 39-40, May \& Avlar 1996, p. 51, May 1997, pp. 295-296, García-Alcalde et al. 2002, p. 75, p. 80). It is important to note that no brachiopod exists in the Givetian and Frasnian that could be confused with Paraspirifer cultrijugatus. Consequently, the El Cueto outcrop is upper Emsian or lower Eifelian in age and belongs (based on the lithology described by Almela \& Revilla 1950) to the Santa Lucía Formation.

Almela \& Revilla (1950) found the lectotype of Phillipsastrea torreana minuta (stock No. 1520D) in the "Sierra Carro" outcrop on a 1,197 m high hill with a limestone band at its summit, one $\mathrm{km}$ west from Aviados (Almela \& Revilla 1950, p. 51). They collected the fossils from the top and the uppermost part of the southern slope of the hill, but unfortunately did not include any useful index brachiopods in their fossil list from the limestones of the Sierra Carro outcrop (Almela \& Revilla 1950, pp. 51-52). Therefore, we cannot be sure that this locality belongs to the upper Emsian or (lower) Eifelian as assumed by Almela \& Revilla (1950), or to the upper Givetian.

\section{Systematic description}

Class Anthozoa Ehrenberg, 1834

Subclass Rugosa Milne-Edwards \& Haime, 1850

Order Stauriida Verrill, 1865

Family Disphyllidae Hill, 1939

Subfamily Paradisphyllinae Jell, 1969

\section{Genus Radiastraea Stumm, 1937}

Type species. - Radiastraea arachne Stumm, 1937.

Diagnosis. - See Hill (1981, pp. 272-275).

Remarks. - Cantabriastraea Schröder \& Soto, 2003, with the type species Cantabriastraea cantabrica Schröder \& Soto, 2003 from the Emsian of the Cantabrian Mountains (Schröder \& Soto 2003, pp. 552-553), is very similar to Radiastraea Stumm, 1937. Schröder \& Soto (2003, p. 553) mention only a few differences of Radiastraea, such as "differently structured tabularium" and "generally complete septa". The arched tabulae of Cantabriastraea makes it even more similar to Radiastraea. Furthermore, the septal development of Radiastraea verrilli (Meek, 1867), redescribed by Pedder (1980, pp. 598-600, pl. 2, figs 5-8), shows some similarities to the septal development of Cantabriastraea cantabrica Schröder \& Soto, 2003. Consequently, it is very doubtful that Cantabriastraea cantabrica Schröder \& Soto, 2003 deserves to be distinguished on a generic level from Radiastraea arachne Stumm, 1937. It is probably only a marginal case of Radiastraea. However, an investigation of the different species of Radiastraea and their variability would be necessary before making a definitive decision.

Occurrence. - Hill (1981, p. 275) gave the geographical and stratigraphical distribution of Radiastraea as the upper Silurian of the Canadian Arctic, the Emsian of Nevada and 
Australia, and the lower Middle Devonian of North America. Subsequently, Hou (1988, pp. 187-188) described two species of Radiastraea from the serotinus conodont zone (upper Emsian) of Sichuan in China, Yu \& Cai (1983, p. 44) described another from the Early Middle Devonian of Gansu (Northwest China), and the Xi' an Institute of Geology and Mineral Resources (1983, pp. 86-87) described four species of Radiastraea from the Devonian of Northwest China. However, up to now Radiastraea had not been known from Europe or other parts of Asia.

\section{Radiastraea arachne Stumm, 1937}

Figure 2A-C

* 1937 Radiastraea arachne Stumm, n. sp.; Stumm, pp. 439-440, pl. 53, fig. 13, pl. 55, fig. 8 .

1940 Radiastraea arachne Stumm. - Merriam, p. 53, 105, pl. 13, fig. 5.

v 1950 Phillipsastrea torreana Edw. Haime. - Almela \& Revilla, p. 58 (14), p. 60 (16), pl. 3, fig. 4.

non 1956 Radiastraea arachne Stumm. - Warren \& Stelck, pl. 1 , fig. 8.

1964 Radiastraea arachne Stumm, 1937. - Pedder, p. 447, pl. 72, figs 1-3, pl. 73, figs 1-5.

1974 Billingsastraea nevadensis subsp. arachne (Stumm). Merriam, p. 64, pl. 24, fig. 4 (see for further synonymy).

1976 Radiastraea arachne Stumm, 1937. - Oliver, p. 90, pl. 66, figs 1-4.

Holotype and diagnosis. - See Stumm (1937, pp. 439-440, pl. 53, fig. 13, pl. 55, fig. 8).

Material. - The complete colony figured by Almela \& Revilla (1950, pl. 3, fig. 4) is stored in the palaeontological collection of the Museo Geominero (Madrid) under stock No. 1519D. One transversal and one longitudinal thin section have been prepared from it.

Description. - The corallum is flat discus-shaped with a width of $140 \mathrm{~mm}$ and a thickness of $23 \mathrm{~mm}$. The holotheca on the underside of the corallum shows pock-like bulges that correspond to the corallites of the upper (distal) surface. The holotheca also shows fine growth wrinkles.

The distal surface of the corallum is slightly domed, with calical rims slightly raised (maximum one mm raised) above the calicular platform. The calicular pit is cratershaped, 1-2 mm deep, typically circular in outline, and has a diameter of 2.6-3.6 mm (mostly 3.1-3.4 mm). The distances between neighbouring calical centres range between 6.0-12.5 mm (mostly 8.0-10.5 mm).

The transversal section shows that the corallum is normally thamnasterioid. Parts of the corallum are only rarely aphroid, where a gap is developed between the septa of neighbouring corallites. In the transversal section the corallite diameter is about $10 \mathrm{~mm}$, the distances between neighbouring corallite centres are 7.5-10 $\mathrm{mm}$, and the tabularia have diameters of 2.6-3.1 mm.

All measured corallites have 16 major septa and as many minor septa. The major septa are long and reach deep into the tabularium, but only in places reach the middle of the tabularium. In some corallites a few of the major septa touch each other in the middle of the tabularium. In other corallites, a periaxial space of $0.3-0.5 \mathrm{~mm}$ diameter completely lacks septa. Within the tabularium the major septa are 0.02-0.04 $\mathrm{mm}$ thick. They are straight or slightly wavy. At the margin of the tabularium the septa are wedge-shaped dilated.

Minor septa normally extend into the peripheral edge of the tabularium. But in rare cases the minor septa are slightly shorter and do not reach the peripheral edge of the tabularium.

In a part of the dissepimentarium that is close to the tabularium, all septa are remarkably thickened: Major septa are $0.12-0.2 \mathrm{~mm}$ (mostly $0.15-0.18 \mathrm{~mm}$ ) thick and minor septa are $0.06-0.14 \mathrm{~mm}$ thick. In the peripheral part of the corallites there is no distinction between major and minor septa, they are all $0.04-0.10 \mathrm{~mm}$ thick.

The septa are usually smooth, but occasionally they develop very weak carinae that reach up to $0.04 \mathrm{~mm}$ into the lumen.

The longitudinal section shows a tabularium of $2.5-2.9 \mathrm{~mm}$ diameter, which is very clearly separated from the dissepimentarium. Complete tabulae occur only rarely. The complete tabulae are generally horizontally oriented. The vast majority of the tabulae are incomplete (= tabellae). Significantly, the tabellae are axially domed, which is typical for Radiastraea (Pedder 1964, p. 446). Periaxially elevated tabellae may be present. In the middle of the tabularium the tabellae are separated $0.06-0.6 \mathrm{~mm}$ from each other. Over a vertical distance of $5 \mathrm{~mm}$ the number of tabellae amount to 25 .

The dissepiments are curved (globose to elongate). They are oriented vertically within the first row at the boundary to the tabularium. From there to the periphery, the orientation of the dissepiments rapidly becomes horizontal. Normally the dissepiments are approximately horizontally oriented. However, a very slight downward inclination from the inner boundary of the dissepimentarium to the periphery of the corallite is visible.

Remarks. - Without the use of thin sections it is difficult to distinguish this species from Phillipsastrea torreana (Milne-Edwards \& Haime, 1851; see below). Perhaps the occurrence of pock-like bulges on the underside of the corallum may serve as a distinctive mark, as neither Phillipsastrea torreana var. minuta Almela \& Revilla, 1950, nor a colony of Phillipsastrea torreana torreana (Milne-Ed- 
wards \& Haime, 1851) in the Museo Geominero show these bulges (see below).

However, the longitudinal and transversal sections show the typical characteristics of the genus Radiastraea Stumm, 1937, and fit well with the descriptions and figures of its type species Radiastraea arachne Stumm, 1937 by Stumm (1937), Pedder (1964), Merriam (1974), and Oliver (1976). Pedder (pers. comm. 2005) considers the existence of periaxially elevated tabellae as a diagnostic feature of Radiastraea arachne. The Spanish material also shows periaxially elevated tabellae, although they are not as well developed as in the holotype (Oliver 1976, pl. 66, fig. 4).

Radiastraea nevadensis (Stumm, 1937) shows some similarities to Radiastraea arachne Stumm, 1937, but has larger corallites with more septa (Stumm 1937, pp. 438-439, pl. 53, fig. 12, pl. 55, fig. 9; Merriam 1974, pp. 63-64, pl. 24, figs 1-3, 5-8). The decision of Merriam (1974) to reduce arachne to a variety of nevadensis is not valid, because arachne was proposed as a species, whereas the name nevadensis pertains to a variety.

Cantabriastraea cantabrica Schröder \& Soto, 2003 from the Emsian of the Cantabrian Mountains (Schröder \& Soto 2003, pp. 553-556, figs 6-9) can be distinguished easily from Radiastraea arachne Stumm, 1937 by the higher number of septa and the much more strongly developed carinae in $C$. cantabrica.

Radiastraea verrilli (Meek, 1867) from the late Eifelian of Canada, redescribed by Pedder (1980, pp. 598-600, pl. 2, figs 5-8), is also very similar to Radiastraea arachne Stumm, 1937, but has more strongly developed carinae. Radiastraea norrisi Pedder, 1980, from the late Eifelian of Canada (Pedder 1980, pp. 600-602, pl. 3, figs 3-6, pl. 4, figs 1-4), is very similar to Radiastraea arachne Stumm, 1937, but has somewhat thicker and less numerous septa, somewhat more strongly developed carinae, and contains more frequent gaps between the septa of neighbouring corallites. Radiastraea tapetiformis (Crickmay, 1960), also from the late Eifelian of Canada (Pedder 1980, p. 598, pl. 2, figs 1-4), has a much smaller corallite diameter and less numerous septa than Radiastraea arachne Stumm, 1937.

Hill (1978, p. 16) classified Phillipsastrea aperta Hill, 1942 from the Emsian of New South Wales with Radiastraea. Nevertheless, Phillipsastrea aperta Hill, 1942 is not comparable with the described corallum, because it has a corallite diameter of 12-15 mm and 19-20 septa of each order (Hill 1942, p. 154, pl. 2, fig. 7; Strusz 1965, pp. 547-549, pls 74, 75).
Radiastraea regularis Yu \& Cai, 1983 from the Early Middle Devonian of Gansu (northwest China) can be easily distinguished from Radiastraea arachne Stumm, 1937 by its corallite diameter of 4.3-8.2 mm and 11-14 septa of each order (Yu \& Cai 1983, pp. 44-45, pl. 10, fig. 2, pl. 11, fig. 4).

Among the four species of Radiastraea described by the Xi'an Institute of Geology and Mineral Resources (1983, pp. 86-87, pl. 26-27) from the Devonian of northwest China, only Radiastraea xiawuraensis Cao (in Xi' an Institute of Geology and Mineral Resources, 1983) is comparable to Radiastraea arachne Stumm, 1937. Radiastraea xiawuraensis $\mathrm{Cao}$ is in all dimensions a little smaller (6-7 mm corallite diameter, 2-2.3 $\mathrm{mm}$ tabularium diameter, 14-15 septa of each order) and the septa are slightly thicker (Xi' an Institute of Geology and Mineral Resources 1983, pp. 86-87, pl. 26, fig. 3). Apparently, Radiastraea xiawuraensis Cao is closely related to Radiastraea verrilli (Meek, 1867) and Radiastraea norrisi Pedder, 1980.

He (in Hou 1988) described two species of Radiastraea from the serotinus conodont zone (upper Emsian) of Sichuan (China) that are clearly distinct from Radiastraea arachne Stumm, 1937: Radiastraea longmenshanensis He with corallites of $6 \mathrm{~mm}$ diameter (in Hou 1988, pp. 187-188, pl. 18, fig. 4), and Radiastraea? ertaiziensis He in Hou 1988 with cerioid astreoid (!) corallites of 6-8 mm diameter and 12-14 septa of each order (Hou 1988, p. 188, pl. 18, fig. 6).

Pedder (pers. comm. 2005) believes that the corallum from the Devonian of western Canada figured by Warren \& Stelck (1956, pl. 1, fig. 8) as Radiastraea arachne is a specimen of Taimyrophyllum stirps (Crickmay, 1960), which is a common late Eifelian species in the Norman Wells region of western Canada. Taimyrophyllum stirps is restricted to the Hume Formation in western Canada; it does not occur in the Hare Indian Shale according to Warren \& Stelck (1956, pl. 1) (Pedder, pers. comm. 2005).

Occurrence. - The type stratum of Radiastraea arachne Stumm, 1937 occurs in the Bartine Member, Eurekaspirifer pinyonensis Zone (Zlichovian, early Emsian) of Nevada (Pedder 1980, p. 598).

All specimens of Radiastraea arachne Stumm, 1937 described or figured by Stumm (1937), Pedder (1964), and Merriam (1974) come from localities in central Nevada.

Following Johnson \& Oliver (1977, p. 1466), Radiastraea arachne Stumm, 1937 is a characteristic coral of the coral zone $\mathrm{D}_{2}$ within the Bartine Member of Nevada. Pedder \& Murphy (2003, p. 602) gave the biostratigraphical

Figure 2. A-C - Radiastraea arachne Stumm, 1937, stock No. 1519D, outcrop "El Cueto", upper Emsian or lower Eifelian limestones (Santa Lucía Formation) of Aviados (Provincia León). • A - calices. • B - transversal thin section. • C - longitudinal thin section. • D-F - Phillipsastrea torreana minuta Almela \& Revilla, 1950, lectotype, stock No. 1520D, outcrop "Sierra Carro", upper Emsian to lower Eifelian limestone (Santa Lucía Formation) or upper Givetian linestones (Portilla Formation) of Aviados (Prov. León). $\bullet$ D - calices. $\bullet$ E - transversal thin section. $\bullet$ F - longitudinal thin section. Scale bar represents $2 \mathrm{~mm}$. 

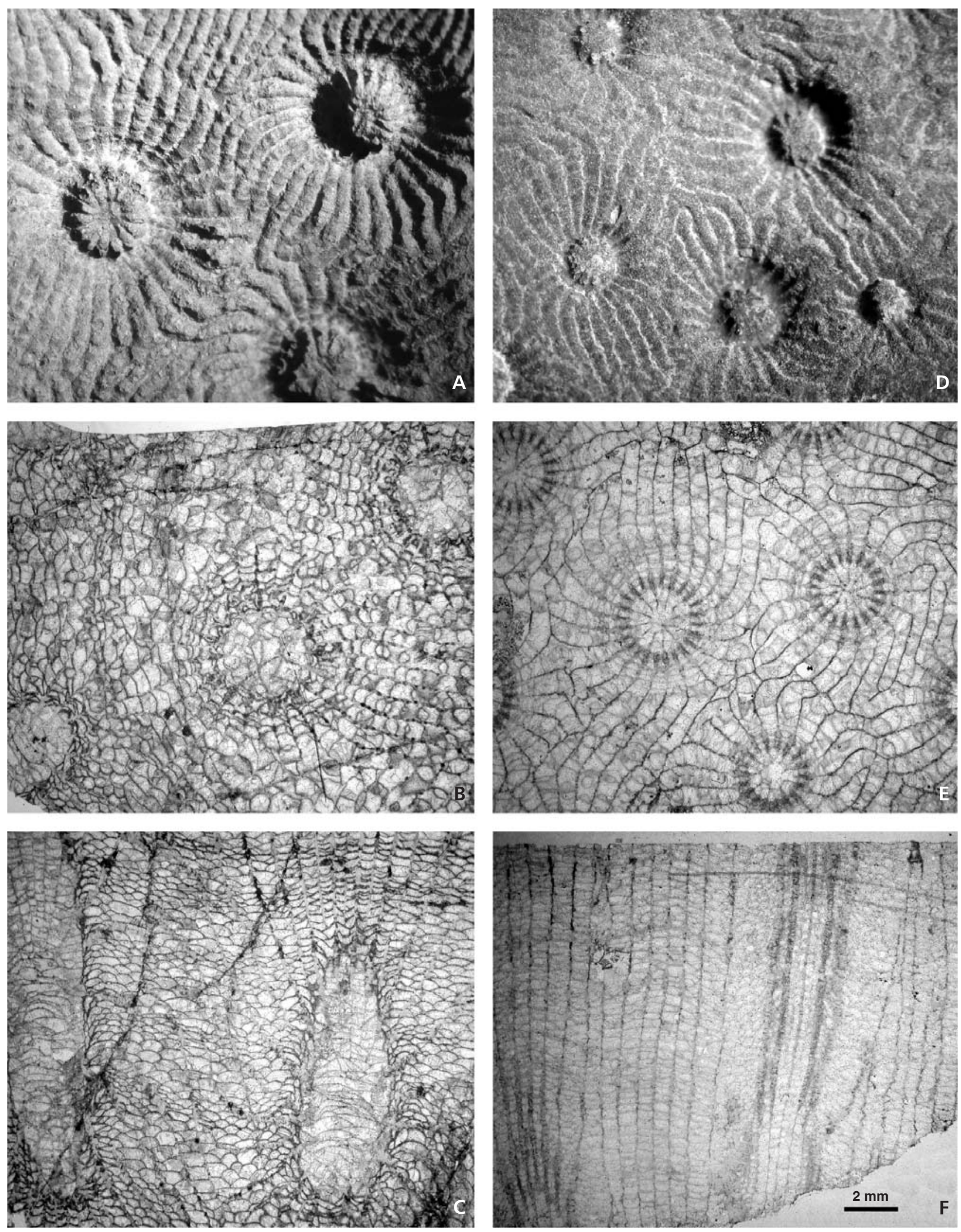
range of the Bartine Member from an upper part of the lenzi conodont zone (lower Emsian) to a lower part of the inversus conodont zone (lower upper Emsian). Pedder \& Murphy (2004, pp. 840, 841) restricted the occurrence of Radiastraea arachne from an upper part of the lenzi conodont zone to a lower part of the gronbergi conodont zone (upper lower Emsian).

Up to now, Radiastraea arachne Stumm, 1937 had only been known from the Emsian of North America. The above described corallum from the upper Emsian or lower Eifelian of Northern Spain does not only expand the geographical distribution of arachne, but also constitutes the first description of the genus Radiastraea in Europe. Remarkably, the European occurrence is only slightly younger than that of the material from Nevada.

Family Phillipsastreidae Hill, 1954

\section{Genus Phillipsastrea d'Orbigny, 1849}

Type species. - Astrea (Siderastrea) hennahii Lonsdale, 1840.

Diagnosis. - See Hill (1981, p. 281) and McLean (1993, p. 53).

Remarks. - There currently exists no full consensus about the definition of the genus Phillipsastrea d'Orbigny, 1849. Since the investigation of Scrutton (1968), most authors have accepted the existence of a pipe of horseshoe dissepiments as an important diagnostic criterion of Phillipsastrea. However, some recent authors refute this: e.g. Birenheide (1978, p. 99) and Sorauf (1998, pp. 70-73). Following Scrutton (1968, pp. 210-214), Hill (1981, p. 281), Coen-Aubert (1986, p. 46; 2002, p. 26), McLean (1989, pp. 239-240; 1993, p. 53; 1994), Errenst (1993, pp. 21-22), and Wang (1994, p. 408), the present author only includes species into this genus that contain an intermittently to completely developed pipe of horseshoe dissepiments.

Occurrence. - For geographical and stratigraphical distribution see Hill (1981, p. 281) and McLean (1993, pp. 57-58). Lists of synonymous genera and assigned species are given by McLean (1993, pp. 53-58) and Wang (1994, pp. 408-414).

\section{Phillipsastrea torreana torreana (Milne-Edwards \& Haime, 1851)}

1850 Phillipsastrea Torreana, n. s.; Verneuil \& Haime, p. 162. (no description, only citation in a fossil list)
* 1851 Syringophyllum? torreanum; Milne-Edwards \& Haime, p. 452.

non 1950 Phillipsastrea torreana Edw. Haime. - Almela \& Revilla, p. 58 (14), p. 60 (16), pl. 3, fig. 4.

2002 Phillipsastrea torreana (Milne-Edwards \& Haime, 1851). - Coen-Aubert, pp. 30-31, pl. 4, figs 1, 2 (see for further synonymy).

non 2005 Phillipsastrea torreana (Milne-Edwards \& Haime, 1851). - Wrzołek, p. 178, fig. 9, tab. 3.

Lectotype. - See Coen-Aubert (2002, p. 30, pl. 4, figs 1, 2).

Diagnosis. - A species of Phillipsastrea with always smooth septa, 11-14 major septa, a tabularium diameter of 2.1-2.7 mm, and an astreoid corallum (Coen-Aubert 2002, p. 30).

Material. - A complete colony from the "Couvinian" of Sierra Carro (Provincia León) stored in the palaeontological collection of the Museo Geominero (Madrid) under the stock No. 1521D. It is probably from the type locality of Phillipsastrea torreana minuta Almela \& Revilla, 1950 or its vicinity.

Description. - The flat discus-shaped corallum 1521D is mostly astreoid and only subordinately thamnasterioid. The corallite diameter is about $6-10 \mathrm{~mm}$, the distance between neighbouring corallite centres is $7.0-9.5 \mathrm{~mm}$, and the tabularium has a diameter of $2.1-2.3 \mathrm{~mm}$. The corallites have 12-13 (usually 12) major septa and as many minor septa. The septa are smooth and lack carinae. The holotheca on the underside of the corallum shows only bulge-like concentric growth zones, which are spaced about $5 \mathrm{~mm}$ apart, and a radial striation produced by the septa. The corallum lacks pock-like bulges or similar structures.

Remarks. - Without the use of thin sections it is difficult to distinguish this species from Radiastraea arachne Stumm, 1937. The observed differences in the development of the holotheca could perhaps be used to distinguish them. However, the longitudinal and transversal sections show the typical characteristics of the genus Phillipsastrea d'Orbigny, 1849.

As explained below, Phillipsastrea torreana minuta Almela \& Revilla, 1950 can be separated only on a subspecific level from Phillipsastrea torreana torreana (Milne-Edwards \& Haime, 1851).

Phillipsastrea torreana torreana (Milne-Edwards \& Haime, 1851) is very similar to Phillipsastrea hennahi hennahi (Lonsdale, 1840) from the Givetian of England, which was redescribed by Scrutton (1968, pp. 214-221, pls 1,2$)$. Both species are not only very similar in appearance, but also have comparable skeletal dimensions. Possible distinctive criteria may be the slightly stronger tendency to 
thamnasterioid growth and sometimes longer major septa in Phillipsastrea hennahi hennahi. Considering the high variability that Wrzołek (1993) described for Phillipsastrea, these criteria could never justify separation on a specific level if it were not for the fact that the septa of Phillipsastrea hennahi hennahi are not always smooth, but sometimes show roughened sides or rudimentary carinae (Scrutton 1968, p. 216; Errenst 1993, pp. 22, 23, fig. 3). The investigation of more material with known stratigraphical positions (see below) would be necessary for estimating the taxonomic importance of this difference in the development of the septa. However, Phillipsastrea torreana (Milne-Edwards \& Haime, 1851) is currently accepted as an independent species.

The material from the upper Givetian of the Cantabrian Mountains classified by Wrzołek (2005, p. 178, fig. 9, tab. 3) with Phillipsastrea torreana (MilneEdwards \& Haime, 1851) does not belong to torreana. In the material of Wrzołek (2005), the septa are not smooth like in torreana, but have weakly developed carinae like in Phillipsastrea hennahi (Lonsdale, 1840). Furthermore, the material of Wrzołek (2005) has remarkably more septa (12.2-18.2 major septa at 7.6-10.5 mm corallite diameter).

Occurrence. - The corallum 1521D described above is of late Emsian to early Eifelian age, or of late Givetian age. Coen-Aubert (2002, p. 30) assumed that the lectotype of Phillipsastrea torreana (Milne-Edwards \& Haime, 1851) from the Cantabrian Mountains probably comes from the Portilla Formation of the upper Givetian. However, considering that the original label of the lectotype states "Sabero, Leon" (Coen-Aubert 2002, p. 30) and that the well known Sabero fossils came from the Emsian of Colle (Fernández et al. 1995, p. 43; García-Alcalde 1999), an (upper) Emsian age of the lectotype of Phillipsastrea torreana (Milne-Edwards \& Haime, 1851) is at least possible.

\section{Phillipsastrea torreana minuta Almela \& Revilla, 1950 Figure 2D-F}

*v 1950 Phillipsastrea torreana Edw. Haime var. minuta nov. var.; Almela \& Revilla, p. 58 (14), p. 60 (16), pl. 3, fig. 5 .

Lectotype. - Almela \& Revilla (1950) did not define a holotype for Phillipsastrea torreana var. minuta. Furthermore, they reported it from both the El Cueto and the Sierra Carro outcrops. Consequently, it is possible, that they had more than one specimen of Phillipsastrea torreana var. minuta. However, the complete colony figured by Almela \& Revilla (1950, pl. 3, fig. 5), which is stored in the palaeon- tological collection of the Museo Geominero (Madrid) under stock No. 1520D, is the only extant specimen. Herewith, this colony (stock No. 1520D), figured by Almela \& Revilla (1950, pl. 3, fig. 5), is chosen as lectotype. One transversal and one longitudinal thin section have been prepared from it.

Diagnosis. - A subspecies of Phillipsastrea torreana (Milne-Edwards \& Haime, 1851) with 10-12 (usually 12) major septa, a tabularium diameter of 1.9-2.1 mm, a distance between neighbouring calical centres of 4.5-10.0 mm (mostly $6.0-7.5 \mathrm{~mm}$ ), and a thamnasterioid to astreoid corallum.

Description. - The corallum is flat discus-shaped with a width of $155 \mathrm{~mm}$ and a thickness of $45 \mathrm{~mm}$. It has calices on the upper and underside surfaces. However, only the well developed and preserved calices of the upper surface are described in what follows.

On the upper surface, the calical rims are raised $0.5-2 \mathrm{~mm}$ above the calicular platform. The calicular pit is crater-shaped, typically circular in outline and has a diameter of 1.6-2.3 mm (mostly 1.9-2.1 mm). The distance between neighbouring calical centres is $4.5-10.0 \mathrm{~mm}$ (mostly 6.0-7.5 mm).

The transversal section shows that the corallum is thamnasterioid to astreoid. The astreoid parts, in which there is a false wall built by the bent endings of the septa separating neighbouring corallites, have a similar frequency as the thamnasterioid parts. Within the transversal section, the corallite diameter is $7-8 \mathrm{~mm}$, the distance between neighbouring corallite centres $6.5-9.0 \mathrm{~mm}$, and the diameter of the tabularium is $1.9-2.1 \mathrm{~mm}$.

The septa are smooth and lack carinae. The measured corallites have 10-12 (mostly 12) major septa and as many minor septa. The major septa are long and reach deep into the tabularium, but in the middle there always remains a space of $0.1-0.6 \mathrm{~mm}$ diameter without any septa. Within the tabularium, the major septa are 0.03-0.04 mm thick. Minor septa end at the peripheral edge of the tabularium or extend up to $0.1 \mathrm{~mm}$ into the tabularium.

The part of the dissepimentarium which is close to the tabularium consists of a pipe of horseshoe dissepiments. Within the area of this pipe all septa and dissepiments are remarkably thickened, building a kind of inner wall. Here the major septa are $0.14-0.20 \mathrm{~mm}$ thick and the minor septa are $0.10-0.18 \mathrm{~mm}$ thick.

In the peripheral part of the corallites there is no distinction in thickness between major and minor septa, all of which are 0.02-0.06 mm (mostly $0.03-0.04 \mathrm{~mm}$ ) thick.

The dissepiments are normally very thin $(0.01-0.02 \mathrm{~mm}$ thick). However, they are thickened within the inner part of the dissepimentarium, and their thickness varies between $0.02 \mathrm{~mm}$ and $0.22 \mathrm{~mm}$. The thickening of the dissepiments is most intensive within the pipe of horseshoe dissepiments. 
The longitudinal section shows a tabularium in which the tabulae are weakly arched and spaced $0.15-0.4 \mathrm{~mm}$ from each other.

The innermost part of the dissepimentarium consists of one row of horseshoe dissepiments of $0.4-0.6 \mathrm{~mm}$ width. The dissepiments are curved (globose to elongate) towards the periphery. They show a downward inclination from the outer boundary of the row of horseshoe dissepiments to the periphery of the corallite. The dissepiments are more or less horizontally oriented at the periphery of the corallite.

Remarks. - The lectotype of Phillipsastrea torreana var. minuta Almela \& Revilla, 1950 has the typical characteristics of the genus Phillipsastrea d'Orbigny, 1849, and shows many similarities with the description of the lectotype of Phillipsastrea torreana (Milne-Edwards \& Haime, 1851) given by Coen-Aubert (2002, pp. 30, 31, pl. 4, figs 1,2). However, the lectotype of minuta is somewhat smaller in all skeletal dimensions, and, furthermore, the thamnasterioid parts have a higher frequency in minuta than in torreana.

Two facts suggest that the differences between the lectotypes of torreana and of minuta are not only the normal variation expected within one population: 1) in the present article a corallum is described that fits very well with the lectotype of Phillipsastrea torreana, and 2) Almela \& Revilla (1950) reported minuta from two different outcrops. However, considering the high variability that Wrzołek (1993) described from Phillipsastrea, Phillipsastrea torreana minuta Almela \& Revilla, 1950 can be separated only on a subspecific level from Phillipsastrea torreana torreana (Milne-Edwards \& Haime, 1851).

Phillipsastrea torreana minuta Almela \& Revilla, 1950 shows some similarities to Phillipsastrea hennahi hennahi (Lonsdale, 1840) from the Givetian of England, which was redescribed by Scrutton (1968, pp. 214-221, pls 1, 2). Phillipsastrea hennahi hennahi has somewhat larger skeletal dimensions than Phillipsastrea torreana minuta, and its septa sometimes have roughened sides or rudimentary carinae (Scrutton 1968, p. 216; Errenst 1993, pp. 22, 23, fig. 3).

Phillipsastrea hennahi ussheri Scrutton, 1968 from the lower Frasnian of England has a comparable tabularium diameter and number of septa, but is distinguished from Phillipsastrea torreana minuta Almela \& Revilla, 1950 by its strongly dilated septa, which form a dense inner wall (Scrutton 1968, pp. 221-226, pl. 3).

Phillipsastrea hennahi ranciae Coen-Aubert, 1986 from the upper Frasnian of Belgium (Coen-Aubert 1986, pp. 48-49, pl. 2) is very similar to Phillipsastrea hennahi ussheri Scrutton, 1968. P. hennahi ranciae has a dense inner wall, a slightly smaller number of septa, and a smaller tabularium, distinguishing it from Phillipsastrea torreana minuta Almela \& Revilla, 1950.
Phillipsastrea torreana minuta Almela \& Revilla, 1950 shows strong similarities to Phillipsastrea tafilaltensis Coen-Aubert, 2002 from the upper Givetian of Marocco (Coen-Aubert 2002, pp. 28, 29, pl. 1, fig. 8, pl. 2). However, in Phillipsastrea tafilaltensis the major septa leave a broad free space within the tabularium and the septa have some rudimentary carinae.

Phillipsastrea liujingensis Yu \& Kuang, 1982 from the late Middle Devonian of Guangxi, China (Yu \& Kuang 1982, pp. 258-259, pl. 2, fig. 4, pl. 3, fig. 1), and from the early Frasnian of Yunnan, China (Wang 1994, pp. 416-418, pls 61, 62) are very similar to Phillipsastrea torreana minuta Almela \& Revilla, 1950. However, there are small carinae present on the sides of the septa of $P$. liujingensis that distinguish it from Phillipsastrea torreana minuta Almela \& Revilla, 1950. Phillipsastrea liujingensis Yu \& Kuang, 1982 is probably only a subspecies of Phillipsastrea hennahi (Lonsdale, 1840).

Phillipsastrea linearis Hill, 1942 from the late Emsian (Pedder, pers. comm. 2005) of New South Wales (Hill 1942, pp. 153-154, pl. 3, fig. 6) has similar skeletal dimensions as Phillipsastrea torreana minuta Almela \& Revilla, 1950. However, in $P$. linearis the major septa are shorter and may be developed as discrete trabeculae.

Some colonies of Pachyphyllum minutissimum Webster, 1905 from the Frasnian of Iowa (Sorauf 1998, pp. 73-75, pl. 36, fig. 5, pls 37, 38) have skeletal dimensions similar to those of Phillipsastrea torreana minuta Almela $\&$ Revilla, 1950. However, the former are distinguished by the shorter major septa and the stronger thickening within the ring of horseshoe dissepiments.

Occurrence. - Phillipsastrea torreana minuta Almela \& Revilla, 1950 is currently known only from the upper Emsian to lower Eifelian or the upper Givetian of Northern Spain.

\section{Palaeobiogeographical relationships}

The Lower and Middle Devonian shallow marine fauna has been divided into three marine faunal realms: the 1) Malvinokaffric Realm (central and southern South America, South Africa, Antarctica); 2) Eastern Americas Realm (eastern United States and eastern Canada, and northwestern South America); and 3) Old World Realm (western United States and western and northern Canada, Europe, northwestern Africa, Asia, and Australia) (Boucot 1988; Stock 2005a, p. 91). All parts of Spain clearly belong to the Old World Realm. One example of a rugose coral typical for the Old World Realm is Phillipsastrea.

The Eastern Americas Realm and the Old World Realm were separated by a land barrier in what is now North America. This barrier was composed of the Canadian Shield and the Transcontinental Arch (Oliver 1977; Stock 
2005a, p. 93, fig. 3). In this context it is very interesting to look for evidence of a breach in the barrier. Findings of Eastern Americas faunal elements in Spain provide such evidence.

Several examples of migration between the Eastern Americas Realm (or America in general) and Spain are known from the Devonian. However, two restrictions must be noted:

1. Almost all examples come from the Cantabrian Mountains. The only exception is the rugose coral Synaptophyllum oliveri Rodríguez García, 1978 from the Emsian of the Sierra Morena in southern Spain (Rodríguez García 1978, p. 344-346). It is not entirely clear if this difference in the amount of examples results only from the lower degree of investigation in the Devonian of the Sierra Morena, or if it reflects a different degree of connection to the Eastern Americas Realm. However, the stromatoporoid fauna of the Sierra Morena is a typical fauna of the Old World Realm and shows no relation to the Eastern Americas fauna (May 2006).

2. Many of the known cases refer to the Middle Devonian of the Cantabrian Mountains. Examples of this include the rugose corals described by Oliver \& Sorauf (1988) and Plusquellec (2005), and the rugose corals and tabulate corals cited by Oekentorp (1975, pp. 76-78) and Soto (1979, p. 404).

The increase of faunal migration in the Middle Devonian is not surprising, as the sea-level rise during the Middle Devonian gradually weakened this barrier until its final breakdown in the Givetian in the Taghanic Event (May 1996, 1997, Stock 2005b).

On the other hand, close palaeobiogeographical relationships between Spain and the Eastern Americas Realm during the Emsian and lower Eifelian would be remarkable because the Emsian was the time of strongest faunal provincialism during the Devonian period (Boucot 1988, pp. 211-212, p. 219; Pedder \& Oliver 1990, p. 267; Oliver \& Pedder 1994, p. 185; May 1996, p. 39). Nevertheless, these palaeobiogeographical relationships are supported by the finding of the Radiastraea arachne Stumm, 1937 described above.

That this finding is not an anomaly, but part of a common pattern, is demonstrated by the publications of Soto (1979; 1981; 1986, p. 34), Fernández-Martínez \& Tourneur (1995), and May (2005), all of whom discerned close palaeobiogeographical relationships between the Cantabrian Mountains and America during the Emsian in different groups of rugose and tabulate corals.

Furthermore, observations in North America suggest the existence of connections between the Eastern Americas Realm and the Old World Realm during the Emsian. For example, a breach in the Transcontinental Arch is thought to have occurred from lower Pragian through lower Ems- ian, when Eastern Americas taxa invaded the Great Basin of the southwestern United States (Stock 2005b, p. 77). Another case involves four stromatoporoid species that occur in North America on both sides of the barrier in close proximity to the Emsian-Eifelian boundary (Stock 2005a, p. 95). However, it remains unclear whether the migration of Radiastraea arachne occurred via one of these breaches or by another breach. For example, in the case of the four stromatoporoid species it is assumed that this migration only was possible because stromatoporoids probably possessed unique ecological tolerances that allowed them to traverse the Devonian transcontinental barrier (Prosh \& Stearn 1993, p. 2473; Stock 2005a, p. 95). Consequently, Radiastraea arachne probably wouldn't have been able to use this breach.

\section{Conclusions}

The finding of Radiastraea arachne Stumm, 1937 in the Cantabrian Mountains is remarkable for two reasons: it is the first reported occurrence of the genus Radiastraea from Europe, and it is an example of close palaeobiogeographical relationships between the Cantabrian Mountains and North America. Comparable patterns have been reported by Soto $(1979 ; 1981 ; 1986$, p. 34), Fernández-Martínez \& Tourneur (1995), and May (2005), all of whom were able to discern close palaeobiogeographical relationships between the Cantabrian Mountains and America during the Emsian in different groups of rugose and tabulate corals. These close palaeobiogeographical relationships are remarkable because the Emsian was the time of strongest faunal provincialism during the Devonian period (Boucot 1988, pp. 211, 212, p. 219; Pedder \& Oliver 1990, p. 267; Oliver \& Pedder 1994, p. 185; May 1996, p. 39). It is also remarkable that the European occurrence of Radiastraea arachne Stumm, 1937 is only slightly younger than the material from Nevada. Radiastraea arachne Stumm, 1937 may prove to be a useful index fossil for Emsian (and possibly early Eifelian) age.

\section{Acknowledgements}

Without the support of the following persons, this investigation would not have been possible: Antonio Perejón Rincon (Universidad Complutense Madrid) proposed I investigate the collections of the Museo Geominero. Isabel Rábano Gutiérrez del Arroyo, the director of the Museo Geominero, permitted me to carry out this research and supported it. Silvia Menéndez Carrasco, the custodian of the palaeontological collections of the Museo Geominero, supported my research in various ways. Alan E.H. Pedder (Geological Survey of Canada, Calgary) gave important information and proof-read the English of the article. Tomasz Wrzołek (University of Silesia, Sosnowiec, Poland) and Arnošt 
Galle (Geological Institute, Academy of Sciences of the Czech Republic, Prague) reviewed the article and gave very helpful suggestions. For all this support I am very thankful. This article is a contribution to the IGCP 499 "Devonian land-sea interaction: evolution of ecosystems and climate".

\section{References}

Almela, A. \& Revilla, J. DE la 1950. Especies fósiles nuevas del devoniano de León. Notas y comunicaciones del Instituto Geológico y Minero de España 20, 47-60 (3-16).

BIRENHEIDE, R. 1978. Rugose Korallen des Devon. Leitfossilien 2, 1-265.

BouCOT, A.J. 1988. Devonian biogeography: an update, 211-227. In McMillan, N.J., Embry, A.F. \& Glass, D.J. (eds) Devonian of The World, Volume III: Paleontology, Paleoecology and Biostratigraphy. Canadian Society of Petroleum Geologists, Memoir 14.

Coen-Aubert, M. 1986. Nouvelles sous-espèces de Phillipsastrea hennahi (Lonsdale, W., 1840) dans le Frasnien supérieur de la Belgique. Bulletin de l'Institut royal des Sciences naturelles de Belgique, Sciences de la Terre 56, 45-55.

Coen-Aubert, M. 2002. Nouvelles espèces du genre Phillipsastrea d'Orbigny, 1849 près de la limite Givetien-Frasnien dans le Tafilalt et le Ma'der au Maroc et notes sur des types espagnoles. Coral Research Bulletin 7, 21-37.

CRICKMAY, C.H. 1960. The older Devonian faunas of the Northwest Territories. $12 \mathrm{pp}$. Calgary (published by the author).

EHRENBERG, C.G. 1834. Beiträge zur physiologischen Kenntniß der Corallenthiere im allgemeinen, und besonders des rothen Meeres, nebst einem Versuche zur physiologischen Systematik derselben. Abhandlungen der Köninglichen Akademie der Wissenschaften in Berlin 1832, 225-380.

ERRENST, C. 1993. Koloniebildende Phillipsastreidae und Hexagonariinae aus dem Givetium des Messinghäuser Sattels und vom Südrand des Briloner Massenkalkes (nordöstliches Sauerland). Geologie und Paläontologie in Westfalen 26, 7-45.

FernándeZ, L.P., FernÁndeZ-MartínEZ, E., MÉndeZ-Bedia, I., RodríGUEZ, S. \& SoTO, F. 1995. VII International Symposium on Fossil Cnidaria and Porifera, Field Trip A, September 5-11, 1995: Devonian and Carboniferous reefal facies from the Cantabrian Zone (NW Spain). 76 pp. Madrid.

FERnÁNDEZ-MARTínEZ, E. \& Tourneur, F. 1995. Tabulate coral faunas from the Lower Devonian of Colle and "Plataforma de Arnao" (Cantabrian Mountains, NW Spain). Paleogeographical affinities, 23-24. In COMAS-RENGIFO, M.J., Perejón, A., Rodríguez, S. \& SANDo, W.J. (eds) VII International Symposium on Fossil Cnidaria and Porifera, Madrid, Spain, September 12-15, 1995, Abstracts.

García-AlCALDE, J.L. 1999. Terebratúlidos (Braquiópodos) del Emsiense superior de Colle (Sabero, León, N. de España). Trabajos de Geología 21 (Volumen Homenaje a J. Truyols), 159-176.

García-Alcalde, J.L., Carls, P., Pardo Alonso, M.V., SAnZ López, J., Soto, F., Truyols-Massoni, M. \& ValenZUEla-Ríos, J. 2002. Devonian, 67-91. In GibBons, W. \& Moreno, T. (eds) The Geology of Spain. Geological Society, London.
GARCÍA-LÓPEZ, S. 1986. Los conodontos y su aplicación al estudio de las divisiones cronostratigráficas mayores del Devonico asturleonés (España). Parte I, Biostratigrafia. Boletín del Instituto Geológico y Minero de España 97(3), 271-312.

GODEFROID, J. 1980. Le genre Brachyspirifer Wedekind, R., 1926 dans le Siegenien, l'Emsien et le Couvinien du bord meridional du synclinorium de Dinant. Bulletin de l'Institut royal des Sciences naturelles de Belgique, Sciences de la Terre 52(1), 1-102.

HILL, D. 1939. The Devonian rugose corals of Lilydale and Loyola, Victoria. Proceedings of the Royal Society of Victoria (n.s.) 51, 219-256.

HiLl, D. 1942. The Devonian rugose corals of the Tamworth district, N.S.W. Journal and Proceedings of the Royal Society of New South Wales 76, 142-164.

HiLl, D. 1954. Coral faunas from the Silurian of New South Wales and the Devonian of Western Australia. Bulletin of the Bureau of Mineral Resources, Geology and Geophysics, Australia 23, 1-51.

HiLl, D. 1978. Bibliography and index of Australian Palaeozoic corals. Papers, Department of Geology, University of Queensland 8(4), 1-38.

HiLl, D. 1981. Rugosa and Tabulata, i-xl + 1-672. In TeICHERT, C. (ed.) Treatise on Invertebrate Paleontology, Part F, Coelenterata, Suppl. 1. The Geological Society of America and University of Kansas, Lawrence.

Hofmann, M.H. \& Keller, M. 2006. Sequence stratigraphy and carbonate platform organization of the Devonian Santa Lucia Formation, Cantabrian Mountains, NW-Spain. Facies 52(1), 149-167.

Hou HonG-FeI (ed.) 1988. Devonian stratigraphy, paleontology and sedimentary facies of Longmenshan, Sichuan. 487 pp. Geological Publishing House, Beijing. [Chinese with English summary.]

JELL, J.S. 1969. Septal microstructure and classification of the Phillipsastraeidae, 50-73. In CAMPBELL, K.S.W. (ed.) Stratigraphy and Palaeontology. Essays in honour of Dorothy Hill. Australian National University Press, Canberra.

Johnson, J.G. \& OLIVER, W.A., JR. 1977. Silurian and Devonian coral zones in the Great Basin, Nevada and California. Geological Society of America Bulletin 88, 1462-1468.

LONSDALE, W. 1840. Notes on the age of limestones of south Devonshire. Transactions of the Geological Society of London 5, 721-738.

MAY, A. 1996. Relationship among sea-level fluctuation, biogeography, and bioevents of the Devonian: an attempt to approach a powerful, but simple model for complex long-range control of biotic crises. Geolines 3, 38-49.

MAY, A. 1997. Gedanken über Zusammenhänge zwischen Meeresspiegel, Biogeographie und Bio-Events im Devon. Coral Research Bulletin 5, 291-318.

MAY, A. 2005. A new Parastriatopora species (Anthozoa, Tabulata) from the Lower Devonian of Colle (Spain, Cantabrian Mountains). Bulletin of Geosciences 80(4), 287-290.

MAY, A. 2006. Lower Devonian Stromatoporoids from the northern Obejo-Valsequillo-Puebla de la Reina Domain (Badajoz and Córdoba Provinces, Southern Spain). Revista Española de Paleontología 21(1), 29-38. 
MaY, A. \& Avlar, H. 1996. Evolution of Rhenish faunal communities during the Late Emsian and Early Eifelian: three reviews on sedimentation, brachiopods and bioevents. Geolines $3,50-52$.

McLeAn, R.A. 1989. Phillipsastreidae (Rugosa) in the Frasnian of western Canada. Memoir of the Association of Australasian Palaeontologists 8, 239-249.

MCLEAN, R.A. 1993. Frasnian rugose corals of Western Canada. Part 3A: The massive Phillipsastreidae - Phillipsastrea, Chuanbeiphyllum. Palaeontographica, Abt. A 230(1-3), 39-76.

MCLEAN, R.A. 1994. Frasnian rugose corals of Western Canada. Part 3B: The massive Phillipsastreidae - Pachyphyllum, Smithicyathus, Frechastraea. Palaeontographica, Abt. A 230 (4-6), 77-96.

MeEK, F.B. 1867. Remarks on the geology of the valley of Mackenzie River. Transactions of the Chicago Academy of Science 1, 61-114.

MÉndeZ-BediA, I. 1976. Biofacies y Litofacies de la Formación Moniello-Santa Lucía (Devónico de la Cordillera Cantábrica, NW de España). Trabajos de Geología 9, 1-93.

MÉndeZ-Bedia, I., Soto, F. \& FernÁndeZ-MartíneZ, E. 1994. Devonian reef types in the Cantabrian Mountains (NW Spain) and their faunal composition. Courier Forschungsinstitut Senckenberg 172, 161-183.

MERriam, C.W. 1940. Devonian stratigraphy and paleontology of the Roberts Mountains region, Nevada. Geological Society of America Special Paper 25, 1-114.

Merriam, C.W. 1974. Lower and Lower Middle Devonian Rugose Corals of the Central Great Basin. U. S. Geological Survey Professional Paper 805, i-v + 1-83.

MiLne-EdwARDS, H. \& HAIME, J. 1850. A monograph of the British fossil corals. First part. Introduction; corals from the Tertiary and Cretaceous Formations. Monographs of the Palaeontographical Society London 3(2) 7, i-lxxxv + 1-72.

Milne-Edwards, H. \& Haime, J. 1851. Monographie des Polypiers fossiles des terrains paléozoiques. Archives $d u$ Muséum d'Histoire Naturelle 5, 1-502.

OEKENTORP, K. 1975. Beschreibung und Systematik devonischer Favositidae Asturiens und Betrachtungen zur Biogeographie nordspanischer Korallenfaunen. Münstersche Forschungen zur Geologie und Paläontologie 37, 1-129.

OLIVER, W.A., JR. 1976. Noncystimorph Colonial Rugose Corals of the Onesquethaw and Lower Cazenovia Stages (Lower and Middle Devonian) in New York and Adjacent Areas. U. S. Geological Survey Professional Paper 869, 1-156.

OLIVER, W.A., JR. 1977. Biogeography of Late Silurian and Devonian rugose corals. Palaeogeography, Palaeoclimatology, Palaeoecology 22, 85-135.

Oliver, W.A., JR. \& Pedder, A.E.H. 1994. Crises in the Devonian history of the rugose corals. Paleobiology 20(2), 178-190.

Oliver, W.A., JR. \& SORAuF, J.E. 1988. Heliophyllum Hall and Charisphyllum n. gen. (Devonian rugose corals) of the Cantabrian Mountains (NW Spain). Trabajos de Geología 17, 3-17.

D'Orbigny, A. 1849. Note sur des polypiers fossils. 12 pp. Paris.

PEDDER, A.E.H. 1964. Correlation of the Canadian Middle Devonian Hume and Nahanni formations by tetracorals. Palaeontology 7(3), 430-451.
PedDeR, A.E.H. 1980. Devonian corals of late Eifelian age from the Ogilvie Formation of Yukon Territory. Canadian Journal of Earth Sciences 17(5), 594-616.

Pedder, A.E.H. \& Murphy, M.A. 2003. The Papiliophyllidae (Lower Devonian Rugosa): Their systematics and reinterpreted biostratigraphic value in Nevada. Journal of Paleontology 77(4), 601-624.

Pedder, A.E.H. \& Murphy, M.A. 2004. Emsian (Lower Devonian) Rugosa of Nevada: Revision of systematics and stratigraphic ranges, and reassessment of faunal provincialism. Journal of Paleontology 78(5), 838-865.

PedDer, A.E.H. \& Oliver, W.A., JR. 1990. Rugose coral distribution as a test of Devonian palaeogeographic models, 267-275. In MCKerrow, W.S. \& SCOTESE, C.R. (eds) Palaeozoic palaeogeography and biogeography. Geological Society of London, Memoir 12.

Plusquellec, Y. 2005. Hadrophyllum asturicum n. sp., Rugosa du Dévonien de la Chaîne Cantabrique (Espagne): seul représentant du genre hors l'Amérique du Nord. Neues Jahrbuch für Geologie und Paläontologie Monatshefte 2005(1), 46-64.

Prosh, E.C. \& StEarn, C.W. 1993. Early Devonian age of the Detroit River Group, inferred from Arctic stromatoporoids. Canadian Journal of Earth Sciences 30, 2465-2474.

RABANO, I. \& ARRIBAS, A. 1997. Los ejemplares tipo y figurados de las colecciones paleontológicas del Museo Geominero. I. Invertebrados e icnofosiles paleozoicos. Boletín Geológico y Minero 108(3), 229-233.

RoEMER, C.F. 1844. Das rheinische Übergangsgebirge. 96 pp. Hahn, Hannover.

RodríGUEZ GARCíA, S. 1978. Corales rugosos del Devónico de la sierra del Pedroso. Estudios geologicos 34, 331-350.

SCHRÖDER, S. \& Soto, F. 2003. Lower Devonian (Emsian) rugose corals from the Cantabrian Mountains, northern Spain. Acta Palaeontologica Polonica 48(4), 547-558.

SCRUTTON, C.T. 1968. Colonial Phillipsastraeidae from the Devonian of south-east Devon, England. Bulletin of the British Museum (Natural History), Geology 15(5), 181-281.

SoRAUF, J.E. 1998. Frasnian (Upper Devonian) rugose corals from the Lime Creek and Shell Rock Formations of Iowa. Bulletins of American Paleontology 113(355), 1-159.

Soto, F. 1979. Considérations paléobiogéographiques sur les Streptelasmatina (Coelenterata, Rugosa) solitaires du Dévonien des Monts Cantabriques (NW de l'Espagne). Geobios 12(3), 399-409.

Soto, F. 1981. Synaptophyllum aus dem Unterdevon des Kantabrischen Gebirges (Nordspanien). Neues Jahrbuch für Geologie und Paläontologie, Monatshefte 1981(2), 91-99.

Soto, F. 1986. Asociaciones coralinas del Devónico astur-leonés (Cordillera Cantábrica, NO de Espańa). Trabajos de Geología 16, 25-35.

Sтоск, C.W. 2005a. Biogeographical barriers, 89-102. In Lieberman, B.S. \& Stigall Rode, A.L. (eds) Paleobiogeography: generating new insights into the coevolution of the earth and its biota. Paleontological Society Papers 11.

Sтоск, C.W. 2005b. Devonian stromatoporoid originations, extinctions, and paleobiogeography: how they relate to the Frasnian-Famennian extinction, 71-92. In OvER, D.J., MoRRow, J.R. \& Wignall, P.B. (eds) Understanding Late Devo- 
nian and Permian-Triassic Biotic and Climatic Events: Towards an Integrated Approach. Elsevier, Amsterdam.

STRUSZ, D.L. 1965. Disphyllidae and Phacellophyllidae from the Devonian Garra Formation of New South Wales. Palaeontology 8(3), 518-571.

Stumm, E.C. 1937. The Lower Middle Devonian Tetracorals of the Nevada Limestone. Journal of Paleontology 11(5), 423-443.

Verneuil, É. DE \& Haime, J. 1850. Polypiers, 161-162. In Verneuil, É. DE Note sur les fosiles dévoniens du district de Sabero (León). Bulletin de la Société Géologique de France 7.

VERRILL, A.E. 1865. Classification of polyps (Ectract condensed from a synopsis of the polypi of the North Pacific Exploring Expedition, under captains Rinngold and Rodgers, U.S.N.). Essex Institute, Proceedings 4, 145-149.

WANG, X. 1994. The rugose coral fauna from the upper part of the Heyuanzhai Formation in Western Yunnan, China. Journal of the Faculty of Science, Hokkaido University, Ser. IV 23(3), 343-553.
WarRen, P.S. \& Stelck, C.R. 1956. Reference fossils of Canada, Part 1. Devonian faunas of Western Canada. Geological Association of Canada, Special Paper 1, 1-15.

WrzoŁeK, T. 1993. Variability in the Devonian tetracoral Phillipsastrea lacunosa (Gürich). Courier Forschungsinstitut Senckenberg 164, 293-300.

WrzoŁeK, T. 2005. Devonian rugose corals of the Phillipsastrea hennahii species group. Acta Geologica Polonica 55(2), $163-185$.

Xi'An Institute of Geology and Mineral Resources (ed.) 1983. Paleontological atlas of Northwest China. Shaanxi, Gansu and Ningxia Volume, Part II. Upper Palaeozoic. 659 pp. Geological Publishing House, Peking. [In Chinese.]

YU, C.-M. \& CAI, Z.-Q. 1983. Early Middle Devonian rugose corals from the Lure Formation of Diebu in Gansu Province. Gansu Geology 1, 1-77.

Yu, C.-M. \& KuANG, G.-D. 1982. Late Middle Devonian rugose corals from Liujing, Heng Xian, Guangxi and their paleoecological significance. Bulletin of the Nanjing Institute of Geology and Palaeontology 4, 241-278. 